Research Article

\title{
Attitude of General Population towards Organ Donation in a Rural Community of Ernakulam District
}

\author{
Anu Jacob Kachappillil', Anjaly Thankachan 2 , Annie K George ${ }^{3}$, Betty Mathew ${ }^{4}$ \\ ${ }^{1}$ Assistant Professor, Department of Medical Surgical Nursing, M.O.S.C. College of Nursing, Kolenchery, Ernakulam, Kerala, India. \\ $2,3,42^{\text {nd }}$ Year Post Basic B.Sc. Nursing Students, MOSC College of Nursing, Kolenchery, Ernakulam, Kerala, India. \\ DOI: https://doi.org/10.24321/2455.9199.202003
}

I $\quad \begin{array}{lllll}\mathbf{N} & \mathbf{F} & \mathbf{O}\end{array}$

Corresponding Author:

Anu Jacob Kachappillil, Department of Medical Surgical Nursing, M.O.S.C. College of Nursing, Kolenchery, Ernakulam, Kerala, India.

E-mail Id:

a.blossoms@gmail.com

Orcid Id:

https://orcid.org/0000-0003-1203-3849

How to cite this article:

Kachappillil AJ, Thankachan A, George AK, Mathew B. Attitude of General Population towards Organ Donation in a Rural Community of Ernakulam District. Int J HealthCare Edu \& Med Inform 2020; 7(1\&2): 16-20.

Date of Submission: 2020-10-15

Date of Acceptance: 2020-10-30
$\begin{array}{llllllll}\mathbf{A} & \mathbf{B} & \mathbf{S} & \mathbf{T} & \mathbf{R} & \mathbf{A} & \mathbf{C} & \mathbf{T}\end{array}$

Background: Organ donation is defined as an act of giving one or more organs, without compensation, for transplantation to another person. For many of the end stage organ diseases, organ transplantation is the most preferred treatment. The need for organ transplantation is higher than the availability. For the transplantation program to be successful awareness regarding organ donation is needed and people must have a positive attitude towards donating organs. The present study was undertaken to assess the attitude of general population towards organ donation residing in a rural community of Ernakulam District.

Materials and methods: A descriptive analytical survey was conducted to assess the attitude of general population towards organ donation. A 5 point likert scale was used to assess the attitude towards organ donation. 100 subjects were selected using convenient sampling technique. The collected data was analysed by using descriptive and inferential statistics

Results: The results of the study revealed that among 100 subjects, $81 \%$ of general population were having positive attitude, $19 \%$ were having neutral attitude and none of the subjects were having negative attitude towards organ donation. Even though majority of subjects were having positive attitude towards organ donation only $34 \%$ subjects were willing for organ donation. There was a significant association between the attitude of general population towards organ donation with demographic variables like religion and history of organ transplantation among family members/ relatives/ friends at $\mathrm{P}<0.05$ level of significance.

Conclusion: The study revealed that majority of the participants were having positive attitude towards organ donation.

Keywords: Attitude, General Population, Organ Donation

\section{Introduction}

"Give yourself and those in need an elixir of life by pledging your organs" according to Mohith Agadi. Donating an organ is highly valued, as it is gifting and saving the life of someone, as one organ donor can save up to eight lives. Organ donation is defined as an act of giving one or 
more organs, without compensation, for transplantation to another person. ${ }^{1}$ Common transplantations include kidneys, heart, liver, pancreas, intestines, lungs, bones, bone marrow, skin, and corneas. Some organs and tissues can be donated by living donors, such as a kidney or part of the liver, part of the pancreas, part of the lungs, or part of the intestines. Even though possible while living, most donations occur only after the donor's death. ${ }^{2}$

Even though organ transplantation has been in practice in India since many years, there was always a discrepancy between the need and availability of organs. More than 5 lakh people die yearly in India due to lack of availability of organs for transplantation. Organ transplantation is the only hope of life for many people suffering from end stage organ diseases, and for majority of them it remains as an unfulfilled dream. ${ }^{3}$

Lack of awareness and negative attitude towards organ donation could be the possible reasons for the gap between the need and availability of organs. Religious and superstitious beliefs, cultural factors, misinformation's related to organ donation, ignorance of general population, and lack of family consensus have been identified as some of the barriers for the successful implementation of organ donation programs in India. ${ }^{4}$ For the success of transplantation program, the public should be aware of its significance and they need to develop a positive attitude towards organ donation. ${ }^{5}$ This study attempted to find out the attitude of general population aged 18 years and above towards organ donation in a selected rural community of Ernakulam district.

\section{Purpose of the Study}

This study was conducted to assess the attitude of general population towards organ donation.

\section{Statement of the Problem}

A descriptive study to assess the attitude of general population towards organ donation in a selected rural community of Ernakulum district.

\section{Objectives}

- To assess the attitude of general population towards organ donation

- To find out the association between the level of attitude of general population towards organ donation with selected demographic variables

\section{Hypothesis (Level of Significance $\mathbf{P}<0.05$ )}

$\mathrm{H} 1$ : There is a significant association between the level of attitude of general population towards organ donation with selected demographic variables.

\section{Materials and Methods}

Setting of the Study: The study was conducted in a rural community of Ernakulam district.
Research Approach: The approach used in this study was descriptive analytical survey design.

Sample: 100 people aged 18 years and above.

Sampling Technique: Convenient sampling technique

Inclusion Criteria: People aged 18 years and above residing in a rural community of Ernakulam district.

\section{Data Collection Instruments}

Section A: Socio demographic variables of general population which contained 10 items.

Section B: 5 point likert scale which contained 15 items to assess the attitude of general population towards organ donation. Each item was rated against a 5 point scale which scores 0- Strongly Disagree, 1- Disagree, 2- Neutral, 3 - Agree, 4- Strongly agree. The maximum score was 60 and minimum score was 0 . An additional question was included (Yes/ No type question) to assess their willingness for organ donation.

\section{Reliability of the tool}

Reliability of the tool was established by split-half method, and the correlation coefficient was $r=0.76$. Hence, the tool was considered reliable and feasible for the main study.

\section{Result}

Data were analysed by descriptive and inferential statistics using Microsoft excel and R software.

Section A: Distribution of socio demographic variables of general population.

Table 1, shows the sociodemographic variables of the study participants. Even though majority of the participants were familiar with the term organ donation, only $2 \%$ of the participants had a relative/ friend, who donated their organs, which reflects the fact that the organ donation rate is poor in this community.

Table I.Frequency and percentage distribution of socio demographic variables of general Population $n=100$

\begin{tabular}{|c|c|c|c|}
\hline $\begin{array}{c}\text { S. } \\
\text { No. }\end{array}$ & $\begin{array}{c}\text { Demographic } \\
\text { Variables }\end{array}$ & $\begin{array}{c}\text { Frequency } \\
\text { (f) }\end{array}$ & $\begin{array}{c}\text { Percentage } \\
\text { (\%) }\end{array}$ \\
\hline 1. & \multicolumn{3}{|c|}{ Age in years } \\
\hline & $18-40$ & 43 & 43 \\
\hline & $41-60$ & 30 & 30 \\
\hline & $>60$ & 27 & 27 \\
\hline 2. & Male Gender & 54 \\
\hline & Female & 46 & 46 \\
\hline & \multicolumn{2}{|c|}{54} \\
\hline 3. & Hindu & 40 & 40 \\
\hline & \multicolumn{4}{|c|}{ Religion } \\
\hline
\end{tabular}




\begin{tabular}{|c|c|c|c|}
\hline & Christian & 60 & 60 \\
\hline 4. & \multicolumn{3}{|c|}{ Marital status } \\
\hline & Married & 84 & 84 \\
\hline & Single & 16 & 16 \\
\hline 5. & \multicolumn{3}{|c|}{ Education } \\
\hline & Illiterate & 12 & 12 \\
\hline & Up to $10^{\text {th }}$ Standard & 27 & 27 \\
\hline & Plus two/ Pre degree & 22 & 22 \\
\hline & Degree and above & 39 & 39 \\
\hline 6. & \multicolumn{3}{|c|}{ Occupation } \\
\hline & Unemployed & 32 & 32 \\
\hline & Daily wager & 22 & 22 \\
\hline & Government job & 12 & 12 \\
\hline & Private job & 31 & 31 \\
\hline & Student & 3 & 3 \\
\hline 7. & \multicolumn{3}{|c|}{ Monthly income in rupees } \\
\hline & $<10,000$ & 70 & 70 \\
\hline & $10,000-20,000$ & 20 & 20 \\
\hline & $21,000-30,000$ & 7 & 7 \\
\hline & $>30,000$ & 3 & 3 \\
\hline 8. & \multicolumn{3}{|c|}{ Have you heard about organ donation? } \\
\hline & Yes & 94 & 94 \\
\hline & No & 6 & 6 \\
\hline & \multicolumn{3}{|c|}{ If yes, source of information } \\
\hline & Television & 60 & 64 \\
\hline & Newspaper & 25 & 27 \\
\hline & Health workers & 6 & 6 \\
\hline & Friends/ Family & 3 & 3 \\
\hline 9. & \multicolumn{3}{|c|}{$\begin{array}{l}\text { History of organ donation among Family } \\
\text { members/ friends/ relatives }\end{array}$} \\
\hline & Yes & 2 & 2 \\
\hline & No & 98 & 98 \\
\hline 10. & \multicolumn{3}{|c|}{$\begin{array}{c}\text { History of organ transplantation among Family } \\
\text { members/ Friends/ Relatives }\end{array}$} \\
\hline & Yes & 2 & 2 \\
\hline & No & 98 & 98 \\
\hline
\end{tabular}

Section B: Attitude of general population towards organ donation.

Table 2, shows the attitude of general population towards organ donation, which was assessed by using a 5 point Likert scale. The maximum score of the attitude scale was 60 and minimum score was 0 . The mean attitude score was
48.09 with standard deviation 5.40. Even though majority of subjects were having positive attitude towards organ donation, only $34 \%$ subjects were willing to donate their organs. These findings show that there exist certain factors rather than attitude which act as barriers for organ donation program in our country.

Table 2.Frequency and percentage distribution of attitude score of general population towards organ donation $n=100$

\begin{tabular}{|c|c|c|c|}
\hline $\begin{array}{c}\text { S. } \\
\text { No. }\end{array}$ & Level of Attitude & $\begin{array}{c}\text { Frequency } \\
\text { (f) }\end{array}$ & $\begin{array}{c}\text { Percentage } \\
\text { (\%) }\end{array}$ \\
\hline 1. & Positive attitude (>45) & 81 & 81 \\
\hline 2. & $\begin{array}{c}\text { Neutral attitude (16- } \\
\text { 45) }\end{array}$ & 19 & 19 \\
\hline 3. & $\begin{array}{c}\text { Negative attitude } \\
(\leq 15)\end{array}$ & 0 & 0 \\
\hline
\end{tabular}

Section C: Association between level of attitude of general population towards organ donation and selected demographic variables.

Table 3, shows that there was a significant association between the attitude of general population towards organ donation with demographic variables like religion ( $p=$ 0.005 ) and history of organ transplantation among family members/ relatives/ friends $(p=0.03)$ at $P<0.05$ level of significance.

Table 3.Association between level of attitude of general population towards organ donation and selected demographic variables $n=100$

\begin{tabular}{|c|c|c|c|c|}
\hline \multirow{2}{*}{$\begin{array}{l}\text { S. } \\
\text { No. }\end{array}$} & \multirow[t]{2}{*}{ Variables } & \multicolumn{2}{|c|}{$\begin{array}{c}\text { Attitude towards } \\
\text { organ donation }\end{array}$} & \multirow[t]{2}{*}{ p-value } \\
\hline & & Neutral & Positive & \\
\hline 1. & \multicolumn{4}{|c|}{ Age in years } \\
\hline & $18-40$ & 4 & 39 & \multirow{3}{*}{0.09} \\
\hline & $41-60$ & 8 & 22 & \\
\hline & Above 60 & 7 & 20 & \\
\hline 2. & \multicolumn{4}{|c|}{ Gender } \\
\hline & Male & 10 & 44 & \multirow[b]{2}{*}{0.89} \\
\hline & Female & 9 & 37 & \\
\hline 3. & \multicolumn{4}{|c|}{ Marital status } \\
\hline & Married & 17 & 67 & \multirow{2}{*}{0.73} \\
\hline & Unmarried & 2 & 14 & \\
\hline 4. & \multicolumn{4}{|c|}{ Religion } \\
\hline & Hindu & 13 & 27 & \multirow{2}{*}{$0.005^{*}$} \\
\hline & Christian & 6 & 54 & \\
\hline
\end{tabular}




\begin{tabular}{|c|c|c|c|c|}
\hline 5. & \multicolumn{4}{|c|}{ Education } \\
\hline & Illiterate & 5 & 7 & \multirow{4}{*}{0.1} \\
\hline & $\begin{array}{l}\text { Up to10th Stan- } \\
\text { dard }\end{array}$ & 5 & 22 & \\
\hline & $\begin{array}{l}\text { Plus two/Pre } \\
\text { degree }\end{array}$ & 5 & 17 & \\
\hline & Degree and above & 4 & 35 & \\
\hline 6. & \multicolumn{4}{|c|}{$\begin{array}{l}\text { Occupation } \\
\end{array}$} \\
\hline & $\begin{array}{l}\text { Unemployed/ } \\
\text { Student }\end{array}$ & 7 & 28 & \multirow{4}{*}{0.62} \\
\hline & Daily wager & 6 & 16 & \\
\hline & Government job & 2 & 10 & \\
\hline & Private job & 4 & 27 & \\
\hline 7. & \multicolumn{4}{|c|}{ Monthly Income } \\
\hline & Below Rs.20,000/- & 17 & 73 & \multirow{2}{*}{1} \\
\hline & Above Rs.20,000/- & 2 & 8 & \\
\hline \multirow[t]{3}{*}{8.} & Have you hearc & out & dor & \\
\hline & Yes & 17 & 77 & \multirow{2}{*}{0.32} \\
\hline & No & 2 & 4 & \\
\hline \multirow[t]{3}{*}{9.} & \multicolumn{4}{|c|}{$\begin{array}{l}\text { History of organ donation among Family mem- } \\
\text { bers/friends/ relatives. }\end{array}$} \\
\hline & Yes & 0 & 2 & \multirow{2}{*}{1} \\
\hline & No & 19 & 79 & \\
\hline \multirow[t]{3}{*}{10.} & $\begin{array}{r}\text { History of organ tr } \\
\text { members }\end{array}$ & plar & lativ & Family \\
\hline & Yes & 2 & 0 & \multirow{2}{*}{$0.03 *$} \\
\hline & No & 17 & 81 & \\
\hline
\end{tabular}

\section{Discussion}

This study was conducted to assess the attitude of general population towards organ donation. The study findings showed that, $81 \%$ of general population were having positive attitude, $19 \%$ were having neutral attitude and none of the subjects were having negative attitude towards organ donation. $34 \%$ participants were willing for organ donation. There was a significant association between the attitude of general population towards organ donation with demographic variables like religion $(p=0.005)$ and history of organ transplantation among family members/ relatives/ friends $(p=0.03)$ at $P<0.05$ level of significance.

In our study, majority of participants, $81 \%$ were having positive attitude towards organ donation. The findings are comparable to a previous study which showed majority, $62 \%$ of participants had moderately favourable attitude towards organ donation. ${ }^{6}$ The results were also comparable to two similar previous studies which showed that $58 \%$ and $67 \%$ of participants were having positive attitude towards organ donation. ${ }^{4,1}$

Another significant finding of our study was that even though majority of the subjects were having positive attitude towards organ donation, only $34 \%$ subjects were willing to donate their organs. The findings can be compared to a previous study that showed even though more than half of the participants were having positive attitude towards organ donation, only $2.3 \%$ had registered for the same. ${ }^{4} \mathrm{~A}$ similar study also concluded that even though majority of the participants had a positive attitude, $62.2 \%$ were willing to donate their organs. ${ }^{1}$

Our study established a significant association between the attitude of general population towards organ donation with demographic variables like religion and history of organ transplantation among family members/ relatives/ friends at $\mathrm{P}<0.05$ level of significance. A similar study also showed a significant association between the attitude of participants towards organ donation with religion at $\mathrm{P}<0.05$ level of significance. ${ }^{4}$

The finding of our study indirectly shows that there is certain other factors other than attitude which act as the barriers for organ donation program in our country. Opposition from family, fear of death, complications after living organ donation, fear of misuse of organs, religious beliefs etc. could be few among them. Effective measures should be taken by the government and voluntary organizations to overcome these barriers by organizing educational programs which provide relevant information to general public with the involvement of media, religious scholars and medical professionals which in turn will helps to overcome the shortage of organs for transplantation in India. ${ }^{7}$

\section{Conclusion}

The result of the study showed that majority of the subjects $(81 \%)$ had positive attitude towards organ donation and there was a significant association between the attitude of general population towards organ donation with demographic variables like religion and history of organ transplantation among family members/ relatives/friends at $\mathrm{P}<0.05$ level of significance. Even though majority of subjects were having positive attitude towards organ donation, only $34 \%$ subjects were willing to donate their organs.

\section{Acknowledgement}

Here we extend our sincere thanks to all people who participated in the study.

\section{Conflict of Interest: None}




\section{References}

1. Vijayalakshmi, Poreddi, Sunitha TS, Gandhi S, Thimmaiah $R$, Math SB. Knowledge, attitude and behaviour of the general population towards organ donation: an Indian perspective. The National medical journal of India 2016; 29(5): 257.

2. Tamuli, Pratim R, Sarmah S, Saikia B. Organ donation"attitude and awareness among undergraduates and postgraduates of North-East India. Journal of family medicine and primary care 2019; 8(1): 130.

3. Jothula, Kishore Y, Sreeharshika D. Study to assess knowledge, attitude and practice regarding organ donation among interns of a medical college in Telangana, India. Int J Community Med Public Health 2018; 5(4): 1339-1345.

4. Sarveswaran, Gokul, Sakthivel MN, Krishnamoorthy Y, Arivarasan Y, Ramakrishnan J. Knowledge, attitude, and practice regarding organ donation among adult population of urban Puducherry, South India. Journal of education and health promotion 7 (2018).

5. Balajee KL, Ramachandran N, Subitha L. Awareness and attitudes toward organ donation in rural Puducherry, India. Annals of Medical and Health Sciences Research 2016; 6(5): 286-290.

6. Jayabharathi B, Devika M, Akila M. Assessment of knowledge and attitude on organ donation among adults in selected areas. International Journal of Research in Pharmaceutical Sciences 2019; 10(2): 782-786.

7. Flower, Little JR, Balamurugan E. A study on public intention to donate organ: Perceived barriers and facilitators. British Journal of Medical Practitioners 2013; 6(4) 6-10. 